Research, part of a Special Feature on Navigating Trade-offs: Working for Conservation and Development Outcomes

\title{
Addressing Trade-offs: Experiences from Conservation and Development Initiatives in the Mkuze Wetlands, South Africa
}

\author{
$\underline{\text { Annika C. Dahlberg }}^{1}$ and $\underline{\text { Catie Burlando }}^{2}$
}

\begin{abstract}
Present-day conservation policies generally include the aim to integrate biodiversity conservation and local development, and describe this as a win-win solution that can satisfy all interests. This is challenged by research claiming that many efforts fail to match practice to rhetoric. South Africa has made strong commitments to fulfill the dual goals of conservation and development, and the iSimangaliso Wetland Park is promoted as an example of this. We explore present and potential outcomes of conservation and development interventions in a community bordering the Wetland Park through the perspective of different stakeholders, with the aim of uncovering opportunities and risks. In terms of improving local livelihoods as well as involvement in conservation, the success of the studied interventions varied. Local communities may accept restrictions on resource use as a result of realistic and fairly negotiated trade-offs, but if perceived as unjust and imposed from above, then mistrust and resistance will increase. In this area, collaboration between conservation organizations and the local community had improved, but still faced problems associated with unequal power relations, unrealistic expectations, and a lack of trust, transparency, and communication. As unsustainable efforts are a waste of funds and engagement, and may even become counterproductive, policy visions need to be matched by realistic allocations of staff, time, funds, and training. At the national and international level, the true cost of conservation has to be recognized and budgeted for if efforts at integrating conservation and development are to succeed.
\end{abstract}

Key Words: integrated conservation and development; Mkuze wetlands; natural resource management; protected area; rural livelihoods; South Africa; trade-offs

\section{INTRODUCTION}

The fortress-type approach to conservation that has been common in protected-area management throughout the 20th century has been strongly criticized because of its negative impact on local livelihoods (Wilshusen et al. 2002, Dowie 2009). Alternative approaches that aim to integrate conservation and development have been formally endorsed by both national and international conservation organizations (Borrini-Feyerabend et al. 2004). The main reasons for integration relate to poverty alleviation, democracy, human rights, and more efficient conservation, and such efforts commonly include so-called Integrated Conservation and Development Projects (ICDPs) (Adams and Hulme 2001).

The rationale of ICDPs is that economic loss to local communities caused by restricted access to natural resources in protected areas should be compensated through alternative income sources, thereby reducing dependence on these resources and increasing awareness of conservation benefits (Garnett et al. 2007). However, many ICDPs face problems because generated benefits are not sufficient to replace reliance on land and other resources (Schmidt-Soltau 2004) or they attract more people, thereby increasing pressure on natural resources (Wittemyer et al. 2008). The ICDP model has been subjected to similar criticism as that aimed at conventional development projects. That is, projects are often too limited in space and time, initiated and owned by external actors, have inappropriate funding mechanisms, and reach a limited number of people. Furthermore, participation tends to be superficial and promised benefits unrealistic, and an awareness of the broader socialecological context is often lacking (Sayer and Wells 2004, Springer 2009). 
The gap between policy visions and actual outcomes has generated debate concerning whether and how the dual goals of conservation and development may be reconciled (Adams et al. 2004, Brockington et al. 2006, Agrawal and Redford 2009). Some fear that one will take precedence over the other (Sanderson and Redford 2003, Brockington et al. 2006), although many governments, international NGOs, and national conservation organizations state that they believe in win-win scenarios (IUCN 2002, Roe and Elliott 2006). It has been argued that this perceived need for consensus, aimed at satisfying all parties, denies the complexity of the issue and hides important aspects of power relations, politics, and justice (Büscher 2008). Conservation and development do not have to be irreconcilable goals, but they need to be realistically considered as part of a political and social process of engagement and negotiation among different interests (Brechin et al. 2002). The creation of protected areas always entails trading one land-use option for another, and choices among different interests have to be continuously faced. Thus, tradeoffs between the goals of conservation and development, as well as within them, are the norm rather than the exception. Trade-offs are complex, appear in many guises, and are perceived differently depending on the vantage point (Sunderland et al. 2008). This is why the importance of transparency in negotiations has been highlighted (Brown 2004, Wells et al. 2004).

South Africa has an exceptionally high biodiversity, but also a large human population where many have endured unjust, exclusionary conservation practices for over a century. As a result, protected areas are hotly contested (Kepe et al. 2004, Ramutsindela 2004). Since the democratic transition in 1994, the government has embarked on a challenging path aimed at conserving biodiversity, alleviating poverty, and redressing previous dispossessions (Magome and Murombedzi 2003, Carruthers 2007). Northeastern KwaZulu-Natal is a case in point. The region has been severely neglected in terms of development (Guyot 2002) and at the same time many protected areas have been established here, such as the country's first Natural World Heritage Site, the iSimangaliso Wetland Park, formerly named the Greater St. Lucia Wetland Park. The integration of conservation and development in iSimangaliso Wetland Park, hereafter referred to as the Wetland Park, has been described as a win-win situation (Porter et al. 2003), but this has been challenged from both a conservation and a humanrights point of view (Guyot 2002, Jones 2006).
We study the case of one community that borders the Wetland Park to explore opportunities and risks inherent in interventions aimed at integrating conservation and development. The study provides a context-specific analysis of interactions between the Wetland Park and the community, with the aim of drawing some general lessons concerning links between process and outcomes. Here, process refers specifically to the described interventions, but also to the local socio-environmental setting, including changes in land use and management. The qualitative research approach applied allows the interests, experiences, and perceptions of different stakeholders to be heard, as well as juxtaposed and contrasted. Finally, in a discussion based on insights gained, we reflect on varying forms of trade-offs, and how these may relate to the sustainability of different initiatives to promote both conservation and development.

\section{CASE-STUDY AREA}

\section{The Tribal Authority of Mnqobokazi}

The tribal authority of Mnqobokazi extends into the Mkuze wetland, part of which is included in the Wetland Park. People have lived in the area for several hundred years, and according to available census data, the community has about 8000 people (Statistics South Africa 2001). The community is divided into wards, each administered by a headman, Induna, who reports to the tribal chief, Inkosi (Andrén 2001). Since 1994, power and responsibilities have been shared between the traditional leadership and an elected councillor. The area has recently seen some improvements in infrastructure, such as a local clinic, but overall the level of development is low, as is the educational standard, and the incidence rate of HIV and malaria is extremely high. Few people have formal employment, and reliance on pensions and child grants has become increasingly important (Burlando 2005, Dahlberg and Trygger 2009). Many households have access to land in the fertile delta of the Mkuze River for subsistence and smallscale commercial agriculture. Cattle are grazed on communal land and in the protected areas, with the latter being especially important in drought years. People rely heavily on resources from the wetland, such as poles, firewood, reeds used for roofs and mats, ilala palm (Hyphaene coriacea) for baskets and beer, fish, and small game (Dahlberg 2005). This produce is mainly used within the household or sold locally, although reeds, palm leaves, and 
crafts are also sold to middlemen or at tourist markets. This has become an important source of income, especially for poor, female-headed households that are growing in number as a result of the migration of men in search of work and the effects of HIV (Dahlberg 2005).

\section{Environment and Conservation History}

The coastal plain of KwaZulu-Natal is dominated by sandy soils, and the scattered wetlands provide pockets of productive soil important to local agriculture. The Mkuze wetland includes the floodplain of the Mkuze River, streams, pans, and swamps (Ellery et al. 2003). The climate is moistsubtropical, and rainfall, averaging between 600 and $1000 \mathrm{~mm}$, is highly variable and droughts as well as flood events are common. The area constitutes a mosaic of different habitats and vegetation types, where abiotic, biotic, and human influences have contributed to a high plant and animal diversity (Ellery et al. 2003). The demarcation of state land and commercial farms for white farmers during the $20^{\text {th }}$ century reduced the area available to the local black communities (Dahlberg 2005). As in South Africa generally, land is divided among different tenure regimes, categorized as communal, private, or state land. Today, Mnqobokazi is surrounded by protected areas on three sides: the Mkuze Game Reserve, established in 1912, the Phinda Reserve, a commercial wildlife reserve developed in the 1980s, and the iSimangaliso Wetland Park (Fig. 1). These protected areas were formerly accessed by the Mnqobokazi community for settlements, fields, grazing, and hunting (Andrén 2001).

The Wetland Park, covering more than 300000 ha along the coast of KwaZulu-Natal, was proclaimed a World Natural Heritage Site in 1999 (Porter et al. 2003). The part that borders Mnqobokazi was earlier demarcated as a forest reserve, and in the 1970s it was taken over by the military who forcibly evicted the resident Mbila people. The area was later declared conservation land and resource use was further restricted. Cattle grazing and the collection of reeds were allowed, but the collection of firewood and medicinal plants, setting fires, fishing, and hunting became illegal. This had negative consequences for local food security and was perceived as unjust by local people. Hunting was the most contentious issue, where custom and need clashed with official views on poaching. Local hunters entered the protected area at night while game guards patrolled the area in search of poachers, and men on both sides were injured and even killed
(Ellery et al. 2003, Dahlberg 2005). Conservation field staff faced an impossible task, with orders to enforce regulations while simultaneously maintaining good relations with local communities (Andrén 2001). After democratization in 1994, the neighboring Mbila community won a land claim for a large area within the Wetland Park, but on the premise that the land would remain protected. Resettlement was not allowed, but forms for local involvement in resource management were to be negotiated. Other communities that like Mnqobokazi had used the land and its resources but had not been settled there, were not included in this agreement. In 2007, Mnqobokazi gained land title to about 5000 ha inside Phinda Reserve, but also here the land would continue to be managed for conservation.

\section{METHODS}

Previous research in this area has accumulated extensive knowledge about livelihood strategies, natural resource use and dependence, the history of land-use changes, and the relationships between the community and conservation interests. We build on this knowledge to strengthen the analysis of new data. Field work was conducted in April-May 2005, using participant observations and in-depth, semistructured interviews with 56 stakeholders. In Mnqobokazi, 43 people were interviewed, 26 of whom were active in development projects initiated by the park authority. The other respondents from the community were selected to include men and women who were from different wards and who relied on different livelihood strategies such as farming, raising cattle, harvesting wild resources, local employment, and pensions, and included representatives of the local leadership. Questions focused on livelihood strategies, local conservation and development initiatives, and relationships with conservation organizations. Most interviews were conducted in Zulu with the aid of a local interpreter. Interviews were also conducted with staff from conservation organizations. Eight of these were from the provincial conservation organization, Ezemvelo KwaZulu-Natal Wildlife (EKZNW) and five were from the iSimangaliso Authority, and included people with different work duties. Interviews dealt with such topics as the mandate of the organizations, conservation and development efforts, and involvement with local communities. Although not requested by the majority of respondents, most opinions and quotes provided remain anonymous. 
Figure 1. Location of study area (modified from Andrén 2001)

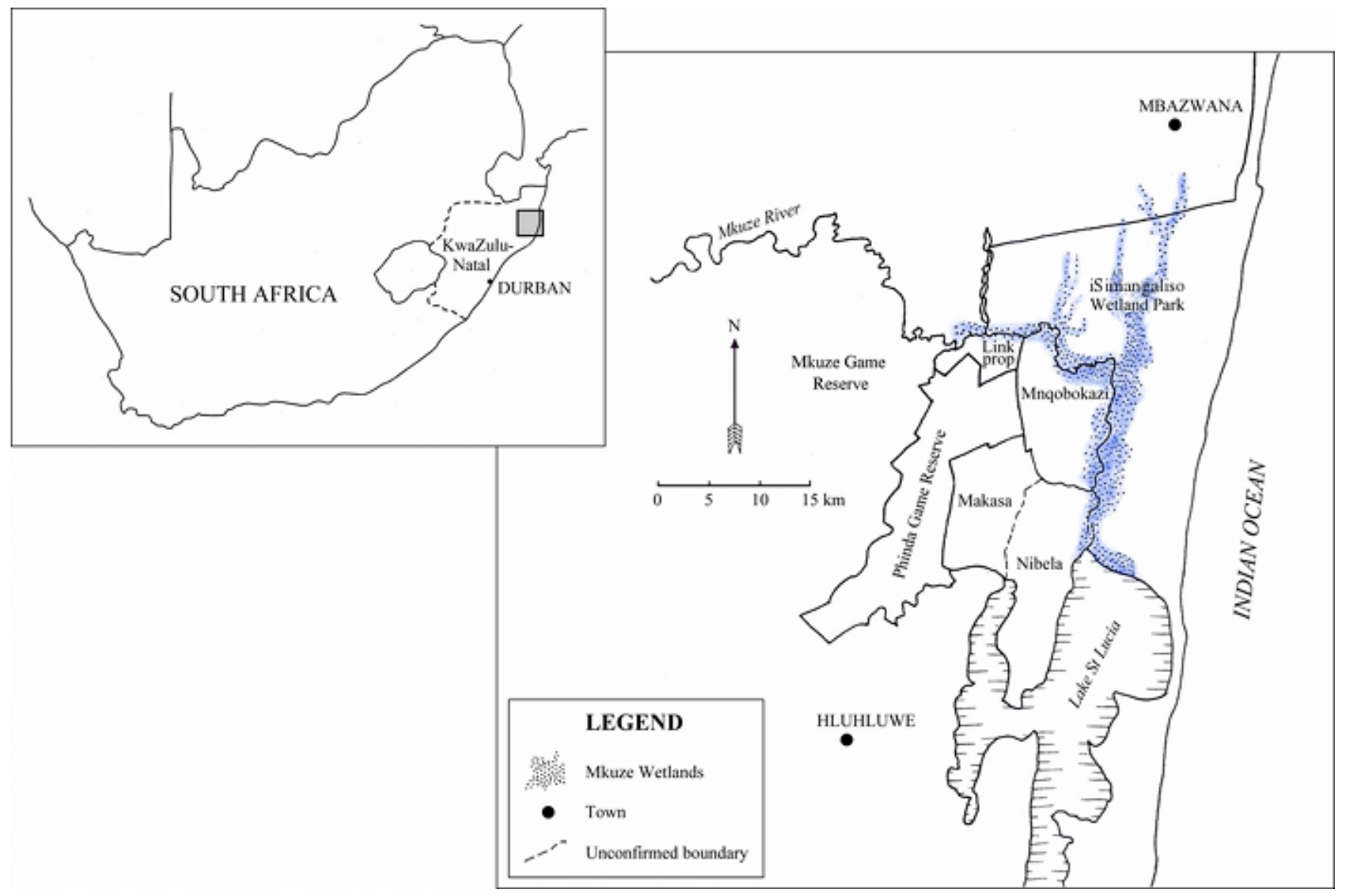

\section{RESULTS}

\section{Mandate and Ambitions of Conservation Organizations}

The study area was part of the Lubombo Spatial Development Initiative (LSDI) that supported development through the promotion of conservation and tourism. The nomination of the country's first World Natural Heritage Site was seen as an ideal way to use tourism to serve both conservation and development interests (Porter et al. 2003). The iSimangaliso Authority (IA) was established in 2000 to promote conservation and development in the region. The Minister of Environmental Affairs and Tourism emphasized the latter: "The new Authority's primary purpose will be to accelerate development, generate sustainable jobs and create conditions for the establishment of an internationally competitive tourism destination" (Moosa 2000).

The overall responsibility for the Wetland Park lay with the IA, and the day-to-day conservation activities were delegated to EKZNW, whose mandate also included local development issues (Porter et al. 2003). In terms of official plans for local participation and development in and around the park as a whole, the IA has stated they plan to involve local communities in such projects as the training of field guides, developing new infrastructure, and small tourism enterprises. Other stated aims are to incorporate indigenous resourcemanagement practices in conservation management and to improve subsistence and small-scale commercial production (Derwent and Porter 2003). In interviews staff added that they hoped that 
communities would suggest projects and stated that "It would be ideal to have the community consider the park as their own asset." To recreate the area's former biodiversity and attract more tourists, wildlife such as elephants, white and black rhino, and buffalo had, during the time of fieldwork in 2005, started to be introduced in the park. At the same time, the IA was negotiating with protected areas that neighbor the Wetland Park to drop fences between them to create larger conservation areas. They also planned to erect new fences along the borders between conservation and communal land, to keep wildlife safely within the park and to protect neighboring communities.

\section{Conservation and Development Initiatives in Mnqobokazi}

\section{Communal gardens}

In 2003, the IA received government funds to initiate communal vegetable gardens in communities bordering the Wetland Park, and in Mnqobokazi they presented this proposal at a public meeting. The first garden here, S'gungunya, was established in 2003, and encouraged by a local Induna and a second garden, Sisonke, was established a year later. The majority of members were women, and to promote their empowerment, the IA required that the garden committees consist of women only. The locations of the gardens were decided jointly by these committees, the Inkosi, and a soil scientist hired by the IA. Both gardens were located high on the bank of a canal to allow for mechanized irrigation while minimizing the risk of flood damage. However, the soils here were sandy and risked rapidly losing fertility with continued cultivation. Staff from the IA said that the women could have selected areas in the more fertile Mkuze River delta, but the local councillor claimed that there was not enough space there for any future expansion of the gardens. Most members were initially satisfied with the locations because the gardens were easily accessible. The IA provided fencing, poles, gates, water tanks, and pipes and hired local workers to set the gardens up. They provided funds for seeds and insecticide, and for a short period they employed a local agricultural extensionist to promote improved farming techniques and commercial skills. In 2005, the first garden had 37 members working 2 ha and the second consisted of 22 members cultivating 1 ha.
In 2003, yields were good and the project was described in the IA newsletter as "Planting seeds to improve lives" (Fakude 2003). In 2004, however, the harvest was poor due to drought, pests, and other problems, and in 2005 planting started late due to heavy rains and administrative misunderstandings. In the Mkuze delta, crops had done better and one member left the project because he could produce more there. In $S^{\prime}$ gungunya garden, there were many complaints. The pump broke, the replacement was inadequate, funds were delayed, too limited, or used inappropriately, communication with the IA faltered, pesticides and a tractor were needed, work was disorganized, and attendance was slack. In the second garden, members were disappointed that the irrigation system had not been installed and that the steep gradient of part of the garden prevented the use of a tractor. However, here members were generally satisfied with the level of organization and cooperation, and they had built a nursery.

According to the IA, the aims with the gardens were to address food security for the poorest, strengthen the skills of farmers, potentially generate income by supplying tourist resorts with vegetables, and create links between the community and the Wetland Park. Knowledge among garden members about these official aims varied. They either did not know of any specific aim with the project, or thought it was to help them support themselves or simply to keep them busy with something useful. Only half of the members interviewed knew the IA had initiated the project, and most did not link the IA to the Wetland Park. This lack of knowledge was more pronounced in the second garden, and according to the IA, this was because it was new and because staff had been relocated elsewhere and not met these members often. All members said crops from their fields in the delta, or income from reeds, mats, or short-term jobs were their main sources of income, and only seven out of 16 mentioned the gardens as a component of their overall livelihood strategy. At the same time, others who lacked access to land wanted to join, but had been told that the garden groups were full. In terms of providing agricultural training, local leaders hoped the gardens would benefit the youth. However, all members already had some farming experience, and no young people had joined. Members were positive about the knowledge learned from the agricultural extensionist and the contact she had initiated with a tourist lodge to buy their vegetables. However, these negotiations had ended when the IA ran short of funds for the project and had to discontinue her contract. The 
main incentive for members to participate in the project was to sell produce outside the community, but other villagers doubted they could meet the necessary demands in quality and volume.

\section{Craft project}

The craft group, Qophumlando, consisted of nine women, six of whom were interviewed including the chairperson. The LSDI initiated the project in 1996, in cooperation with local leadership who selected older women from the poorer households as members. Weaving baskets using leaves of ilala palm was an established local craft. The LSDI provided teachers to train the women to make baskets specifically for the tourism market, and later the IA employed a designer to help the women further improve their products. The official aim of the project was to ensure a monthly income for the women, and members said they had joined the project to earn money, to learn something new, and to work together. Of the original 20 members, three remained. Women had left due to other employment, illness, or because of the demanding quality requirements that also made it difficult to recruit new, and especially young, women to the group. The IA and the women agreed that the group needed more members, but were undecided on how to best realize this. The group had good relationships with staff from the IA, who often visited. Members and IA staff recounted numerous initiatives conducted to increase profitability and sustainability, such as help to establish contacts with buyers and attendance at trade fairs and workshops to meet craft groups from other communities. An important concern for the IA was to ensure that the women were paid appropriately and not taken advantage of. All the women interviewed considered the project a success, and for some it was their main source of income. "I have no pension or child grants, and my only source of cash income is from the baskets. It has meant a big change. Before the family sometimes was very needy, but now they always have something at home to eat." For others, it was a welcome supplement to other income sources such as pensions, child grants, and collecting and selling papyrus. The only problem mentioned was that baskets were rejected, "...even if there is only a small defect," and therefore, a regular income was not assured.

When discussing efforts to promote development in Mnqobokazi, IA staff stressed the success of the craft group, and considered this more successful than the garden project in creating links between conservation and development. The described links consisted of selling crafts to tourists and encouraging people to conserve the ilala trees that were declining on communal land. Staff of the IA said that people who used ilala palms had been taught not to dig up roots, to plant new trees, and not waste weaving material. Group members discussed the increasing scarcity of big palms, but made no mention of any conservation activity. According to them, the increase in people in the community meant more pressure on the ilala, and trees with leaves long enough for weaving were difficult to find on communal land. These could still be found within the Wetland Park, and members usually bought their material from other people in Mnqobokazi who collected inside the park. "...they go in on foot and cut the leaves, and then a tractor will come and collect the bundles."

\section{Hopes and Tensions in Fencing for Conservation}

The IA was involved in negotiations with communities neighboring the park about erecting a fence along their mutual border, with the intent to keep local people and wildlife safe from each other, and to help preserve the wetland. In Mnqobokazi, negotiations about a fence had been temporarily suspended in 2005 awaiting the outcome of the IA's discussions with other communities. Among people in Mnqobokazi, feelings about the proposed fence were mixed. Many knew nothing about it, and those who lived further from the wetland often did not even know the Wetland Park had been established. Among those aware of the plans, many were potentially accepting. As expressed by a male farmer, "The fence is good as long as we can access the resources." These sentiments were echoed in other statements concerning conservation and the Wetland Park, i.e., it was important to protect the Mkuze wetland and its resources, but on the condition that this did not infringe upon peoples' livelihoods. Even when expressing hopes about new jobs as promised by the IA, respondents were still hesitant. "People will gain from the jobs created. They will be the first to be employed for fencing and for the [tourist] lodges. [However], there will be dangerous animals in the park so people won't be allowed to keep their cattle [there]." People feared that the park would not compensate them for reduced access to resources and that a fence could result in increased poverty. Negative effects of 
reduced access would be most noticeable in drought years, when access to reserve grazing land and other resources are especially important. The local leadership felt responsible for securing preferential access to employment in the park for the community. They hoped that the construction of a fence would create jobs, and that a subsequent increase in tourism would generate training and employment opportunities. However, they saw reduced access to natural resources as a problem and were not prepared to give up communal land or accept restrictions on agriculture in the delta.

Staff of the IA were aware of the potential negative socioeconomic effects of a fence and were searching for solutions. Some thought that opportunities for training and work in tourism ventures would outweigh reduced access to resources. Others expressed strong doubts that the number of jobs created would suffice and thought many positions would require an education and experience that local people did not possess. One suggested solution was to plan for gates in the fence to allow local access to natural resources, as had been done in a neighboring community, and to regulate this outtake through a new permit system. However, no concrete plans were mentioned concerning how safe access could be organized and for what natural resources. For many years, the EKZNW had issued permits for the collection of reeds that specified species but not limits on amounts or time of collection. People usually acquired a permit out of fear of penalties, but many thought the system was unnecessary and unfair and were hesitant about complying in the future.

\section{Obstacles and Opportunities}

One community leader was concerned about the benefits promised as compensation for reduced access to resources in the wetland.

When somebody from the community is hungry, they can go and fetch as much iduma [Cyperus papyrus] as they want to buy food. Even if there are permits, these won't be enough... The Authority said that the park will bring in tourists. My question $i s$, how can the profits be divided among the community members when the tourists come?"
Suspicions were raised about a perceived buy-off, as expressed by the same local leader, "The people at the Authority will take my fields [in the delta] with the excuse that they gave us the gardens."

Conservation staff were fully aware that they could not expect local people to give up access to natural resources without compensation. "It is possible to balance use and protection. Before the aim was to protect nature at all costs. Today communities must benefit from the park. We have to find a way to communicate problems and find solutions." Potential solutions mentioned by IA staff included trade-offs. For example, it was suggested that agricultural fields in the wetland located within the park should revert to the community in exchange for areas of communal land. Other forms of compensation that were frequently mentioned involved monetary benefits through the creation of new jobs. Conservation staff aimed at meeting conservation goals as well as addressing the needs of local communities, and this was clearly putting stress on them. Staff members had different responsibilities, often focusing either on conservation or development, and they had to constantly weigh options and accept trade-offs also within their organizations.

Conservation staff who interacted directly with the community said it was important to gain the trust of local people. "The IA should go slower and gain more trust... we also realize that communities can stop projects." However, at times, building trust was described simply as a necessary component of trying to convince local people to accept outside interventions, as exemplified in a discussion about the fence.

Before you do anything, you have to sell the idea. If you want a school, you have to make sure everybody feels the need for it. Same for the conservation area: people need to be convinced. Youmust bring people infrom the start."

Some emphasized the importance of incorporating local knowledge and ideas in decisions about policy and implementation, but also complained how difficult it was to get decision makers to accept, and act upon, local opinion. Awareness of historical processes, cultural characteristics, and socioenvironmental relationships varied among staff members. Some stressed the need to acknowledge 
the historical legacy as well as different world views when negotiating solutions.

\begin{abstract}
Local people have a negative perception of conservation of nature because of the way in which [reserves] were established. The traditional way of conservation is different... Man must make use of the environment to satisfy needs and he must have a responsible attitude.
\end{abstract}

\section{DISCUSSION}

\section{Whither the New Approach to Conservation}

Through their varied responses, the interviewed representatives of the IA, the EKZNW, and the community illustrate the complex and multifaceted nature of combining conservation with development. Conservation staff emphasized that they stood for a new approach to conservation and kept repeating the mantras of "conservation with development," "community involvement," and "respect the voice of the community." However, there were gaps between this rhetoric and reality. How to apply and realize the central components of the "new approach to conservation" were seldom clear either to staff or to local people. At times, simply using the buzz words seemed to create a belief that their content would materialize (Büscher 2008).

The stated official aims of the projects in Mnqobokazi were to increase food and income security among the most vulnerable groups, strengthen the skills of farmers, and increase capacity for small enterprises. By providing alternative livelihood opportunities, local dependence on resources in the wetlands would be reduced. At the time of field work, the communal gardens, the project that involved the most people, already showed signs of being unsustainable. Yields had been poor for two years out of three, and the gardens were evidently more sensitive to rainfall variation than fields in the delta. The project had not managed to target the most vulnerable groups, a common situation in development efforts (Cleaver 2005) and instead mainly included households with other farming opportunities. Members saw the gardens as a positive addition and not as a substitute to other means of survival, consistent with how poor households generally capture opportunities to secure different sources of income (Hulme and Muphree 2001). Participation in the gardens was mainly linked to hopes of accessing commercial markets, but this had not yet materialized, at least partly due to the discontinued employment of the agricultural extensionist. Rural people are generally very knowledgeable about the use and management of local resources, but lack experience and connections to market them. Commercial profitability is usually very difficult to achieve and sustain, even where training has been provided (Nell et al. 2000). Also, a lack of rigor and realism in the planning stage may result in ventures that are not commercially feasible.

The communal garden project in Mnqobokazi can be described as classic example of a traditional blueprint development project, and risked falling short of expectations for common reasons, such as a lack of dialog with local people about needs, aims, and expectations, coupled with a lack of time, funds, and training (Sayer and Wells 2004). The project also lacked the transparency and trust among stakeholders that are especially important when power is unequally divided (Sayer and Campbell 2004). Gaps in communication within the community and inherent differences in power and interests further aggravated the process. The craft group was more successful, mainly because it included important components from the start. The activity was relevant to the participants, training had been continuously provided to enhance their capacity, links with commercial outlets had been established and improved, and participants and funders shared the same aims. However, although it was successful for the participants, their households, and potentially their extended families, it brought benefits to very few in a community of many. In addition, neither of the projects had any clear links to conservation apart from being initiated or funded through the IA, a fact that many participants were unaware of.

\section{Trade-Offs, Perceived Buy-Offs, and Potentially Counterproductive Interventions}

Development projects can create economic incentives that act to decrease pressure on natural resources within protected areas by including tradeoffs where people are offered alternatives and agree to respect conservation efforts. For such trade-offs to be acceptable and sustainable, the alternatives offered, whether money, jobs, or access to other resources, have to outweigh the losses caused by abiding with the restrictions (Schmidt-Soltau 2004). 
Apart from an improved enforcement of existing restrictions, such as the prohibition on hunting and fishing, the IA and EKZNW wanted to reduce the extraction of reeds and palm leaves from the wetland, as well as restrict further agricultural expansion there. However, in Mnqobokazi, households were not working the gardens instead of their fields in the wetland, women did not rely on the sale of vegetables instead of reed mats, and the craft group got most of their raw material from the Wetland Park.

As has been discussed in recent literature, trade-offs within and between conservation and development interests are the norm (Brown 2004, Wells et al. 2004), whether recognized as such or not. The perceived alternative to trade-offs, a win-win situation where none of the parties give up anything, is untenable in most situations (Sanderson and Redford 2003, Wells et al. 2004), although still frequently promoted in policy statements (Adams and Jeanrenaud 2008). The case presented here highlights how important it is that trade-offs are identified, discussed, and negotiated and that how a trade-off is perceived matters more than is often realized. For a trade-off to be accepted in the long term, it has to be transparent and regarded as the outcome of fair negotiations. This does not mean that everyone concerned is satisfied with all aspects of an agreement, but that the process is regarded as just by the majority. Otherwise, concrete outcomes such as reduced access to resources may be perceived as unfair buy-offs they were tricked into or that were enforced from above and therefore rejected outright or through more subtle resistance. This risk increases if past relationships between conservation authorities and local people have been characterized by distrust and violence, as in Mnqobokazi (Andrén 2001). Negotiating trade-offs is further complicated if there exists a high dependence on natural resources, and if this dependence is unequally represented within the community, as in Mnqobokazi (Dahlberg 2005).

The risk of increased local resistance was evident in the study area, where some had started to suspect that the establishment of the communal gardens would be used as an excuse, or a trick, to force people away from their fields and other resources in the wetlands. The plans for a fence between the community and the Wetland Park was a central component here. In South Africa, fences that separate land uses and tenure rights have a problematic and troubled history in that they also forcibly separated people by skin color, wealth, and power. During apartheid, "fences became the material manifestations of ideology" (Sheridan 2008), and this persists today where fences are seen to separate people from their land through a foreign ideology of conservation. However, in Mnqobokazi, a fence may at the same time create opportunities for economic development through increased tourism. Officially, the IA declared that an increase in tourism would result in numerous job and training opportunities, and expectations were high among local people. Although pro-poor tourism strategies are promoted in South Africa (Ashley and Roe 2001, Porter at al. 2003, SANParks 2007), evidence of their effect on local economies is mixed (Kirsten and Rogerson 2002, Cornelissen 2005). Tourism is volatile and seasonal, and therefore demands a high degree of flexibility to remain robust. It tends to be spatially concentrated and involve high capital investment and, therefore, is dominated by external investors (Cornelissen 2005). Generally, although tourism is increasing, few new jobs for local people have been created (Kirsten and Rogerson 2002). Previous studies, as well as present statements by park staff, reveal serious doubts that tourism can become the panacea hoped for in the area (Guyot 2002).

It is evident that the interplay between realized outcomes (e.g., the gardens and the craft group), expected but unrealized outcomes (e.g., jobs in the tourism sector), and existing and expected restrictions (e.g., on resource access) was causing historically embedded negative attitudes toward conservation to resurface. Within this complexity of events and perceptions, outside interventions, irrespective of good intentions, risk becoming counterproductive. The extraction of resources may increase if alternative income sources are insufficient (Kepe et al. 2001, Schmidt-Soltau 2004) and if people perceive they have been tricked into unjust buy-offs. Policies, guidelines, discussions, and negotiations need to be transparent for sustainable change to be achieved (Wells et al. 2004). This is especially important, but also problematic, in areas with an historical legacy of distrust, where stakeholders are unequal in terms of power and skills (Fay 2007). The interviews showed that respect for local practices, views, and needs had increased among conservation staff compared with just half a decade earlier, and that local attitudes toward conservation and the conservation organizations were somewhat improved (Andrén 2001). The present case indicates that existing suspicions, fears, and antagonism toward conservation may be further reduced if the IA can 
bring more time, realism, funds, and transparency to the negotiation table. Among the staff, some were enthusiastic and positive, but others were frustrated and despondent about how to meet the multiple and often conflicting policy demands when they lacked necessary resources.

\section{CONCLUSION}

Despite the many problems that beset ICDPs and other efforts to integrate conservation and development, most studies conclude that a decoupling is not realistic (Brechin et al. 2002, Magome and Murombedzi 2003, Adams et al. 2004). Rather, we must learn from past mistakes to improve the mechanisms of ICDPs (Sunderland et al. 2008) and other efforts to promote conservation and development. Conservation must be recognized as a societal choice, and its costs must be realistically calculated. These costs, which are much higher than generally acknowledged, should not be borne by the local poor. Governments, NGOs, and development agencies must ensure that the staff on the ground can access necessary resources in terms of time, personnel, training, and funds. Whether the outcome in Mnqobokazi will come to represent a fair trade-off or a top-down buy-off will depend on the investments made to promote transparent and fair negotiations toward realistic outcomes.

Responses to this article can be read online at: http://www.ecologyandsociety.org/voll4/iss2/art37/ responses/

\section{Acknowledgments:}

This research was funded by the Swedish International Development Agency (SIDA) through the Department for Research Cooperation (SAREC), and the Swedish Research Council. We are especially indebted to members from the community of Mnqobokazi, and in particular to the late Sam Ngwane. We wish to thank Boni Zikali, Njabulo Ngwane, and Vusi Mduli for field assistance. We are grateful to staff at the iSimangaliso Authority, especially Gordon Fakude, staff at the EKZNW, and colleagues at the former Geography Department, University of KwaZuluNatal, Durban, South Africa. We thank Tor Arve Benjaminsen for comments on an earlier version of the paper, and Bruce Campbell and three anonymous reviewers for constructive comments on the revised version.

\section{LITERATURE CITED}

Adams, W. M., R. Aveling, D. Brockington, B. Dickson, J. Elliott, J. Hutton, D. Roe, B. Vira, and W. Wolmer. 2004. Biodiversity conservation and the eradication of poverty. Science 306:11461149.

Adams, W., and D. Hulme. 2001. Conservation and community: changing narratives, policies and practices in African conservation. Pages 9-23 in D. Hulme and M. Murphree, editors. African wildlife and livelihoods: the promise and performance of community conservation. James Currey, Oxford, UK.

Adams, W. M., and S. J. Jeanrenaud. 2008. Transition to sustainability: towards a humane and diverse world. International Union for Conservation of Nature (IUCN), Gland, Switzerland

Agrawal, A., and K. Redford. 2009. Place, conservation, and displacement. Conservation and Society 7(1):56-58.

Andrén, H. 2001. Wetland resource use in the rainbow nation: a case study of obstacles in sustainable resource management in the Mkuze wetlands, KwaZulu-Natal, South Africa. Minor Field Study No. 146. Uppsala, Sweden.

Ashley, C., and D. Roe. 2001. Making tourism work for the poor: strategies and challenges in southern Africa. Development Southern Africa 19:61-82.

Borrini-Feyerabend, G., A. Kothari, and G. Oviedo. 2004. Indigenous and local communities and protected areas: towards equity and enhanced conservation. IUCN, Gland, Switzerland, and Cambridge, UK.

Brechin, S. R., P. R. Wilshusen, C. L. Fortwangler, and P. C. West. 2002. Beyond the square wheel: toward a more comprehensive understanding of biodiversity conservation as social and political process. Society and Natural Resources 15:41-64. 
Brockington, D., J. Igoe, and K. Schmidt-Soltau. 2006. Conservation, human rights and poverty reduction. Conservation Biology 20(1):250-252.

Brown, K. 2004. Trade-off analysis for integrated conservation and development. Pages 232-255 in T. O. McShane and M. P. Wells, editors. Getting biodiversity projects to work: towards more effective conservation and development. University Press, New York, New York, USA.

Burlando, C. 2005. Negotiating conservation and development in a South African World Heritage Site. Thesis. Department of Biology and Center for Transdisciplinary Environmental Research, Stockholm University, Sweden.

Büscher, B. E. 2008. Conservation, neoliberalism, and social science: a critical reflection on the SCB 2007 annual meeting in South Africa. Conservation Biology 22(2):229-231

Carruthers, J. 2007. South Africa: a world in one country: land restitution in national parks and protected areas. Conservation and Society 5 (3):292-306.

Cleaver, F. 2005. The inequality of social capital and the reproduction of chronic poverty. World Development 33(6):893-906.

Cornelissen, S. 2005. Tourism impact, distribution and development: the spatial structure of tourism in the Western Cape Province of South Africa. Development Southern Africa 22(2):163-185.

Dahlberg, A. C. 2005. Local resource use, nature conservation and tourism in Mkuze wetlands, South Africa: a complex weave of dependence and conflict. Danish Journal of Geography 105(1):113.

Dahlberg, A. C., and S. Trygger. 2009. Lay knowledge of medicinal plants: primary health care and natural resources in rural South Africa. Human Ecology 37(1):79-94.

Derwent, S., and R. Porter. 2003. Benefits beyond boundaries: field visits to protected areas in KwaZulu-Natal, South Africa, 14-15 September 2003. Prepared for the Fifth World Parks Congress, Durban, South Africa.

Dowie, M. 2009. Conservation refugees: the hundred year conflict between global conservation and native peoples. MIT Press, Cambridge, Massachusetts, USA.

Ellery, W. N., A. C. Dahlberg, R. Strydom, M. J. Neal, and J. Jackson. 2003. Diversion of water flow from a floodplain wetland stream: an analysis of geomorphological setting and hydrological and ecological consequences. Journal of Environmental Management 68:51-71.

Fakude, G. 2003. Planting seeds to improve lives. Wetlands Wire 1(2):5. [online] URL: http://www.lub ombomapping.org.za/GSLWPA/web/WW2/page5. $\underline{\mathrm{htm}}$

Fay, D. A. 2007. Mutual gains and distributive ideologies in South Africa: theorizing negotiations between communities and protected areas. Human Ecology 35:81-95.

Garnett, S. T., J. Sayer, and J. Du Toit. 2007. Improving the effectiveness of interventions to balance conservation and development: a conceptual framework. Ecology and Society12(1): 2. [online] URL: http://www.ecologyandsociety.org/ vol12/iss1/art2/

Guyot, S. 2002. Spatial competition and the new governance framework in Mabibi (Maputaland): implications for development. The Geographical Journal 168(1):18-32.

Hulme D., and M. Murphree. 2001. African wildlife and livelihoods: the promise and performance of community conservation. Currey, Oxford, UK.

IUCN. 2002. Beyond rhetoric: putting conservation to work for the poor. IUCN, Gland, Switzerland.

Jones, J. L. 2006. Dynamics of conservation and society: the case of Maputaland, South Africa. Thesis. Faculty of Natural and Agricultural Sciences, University of Pretoria, Pretoria, South Africa.

Kepe, T., B. Cousin, and S. Turner. 2001. Resource tenure and power relations in community wildlife: the case of Mkambati Area, South Africa. Society and Natural Resources 14:911-925.

Kepe, T., M. Saruchera, and W. Whande. 2004. Poverty alleviation and biodiversity conservation: a South African perspective. Oryx 38(2):143-145. 
Kirsten, M., and M. Rogerson. 2002. Tourism, business linkages and small enterprise development in South Africa. Development Southern Africa 19 (1):29-59.

Magome, H., and J. Murombedzi. 2003. Sharing South African national parks: community land and conservation in a democratic South Africa. Pages 108-134 in W. M. Adams and M. Mulligan, editors. Decolonizing nature: strategies for conservation in a post-colonial era. Earthscan, London, UK.

Moosa, V. 2000. Lubombo TFCA protocol: development and investment. Signing of Lubombo protocol. Address by Minister Valli Moosa, 22 June 2000. Department of Environmental Affairs and Tourism, Pretoria, South Africa. [online] URL: $\underline{\text { htt }}$ p://www.environment.gov.za/newsmedia/ speeches/2000jun22/lubombo 22062000.htm

Nell, W., B. Wessels, J. Mokoka, and S. Machedi.. 2000 A creative multidisciplinary approach towards the development of food gardening. Development Southern Africa 17(5):807-819.

Porter, R., M. Swift, B. James, D. Scott, A. Zaloumis, M. Makgolo, and G. Palmer. 2003. World Heritage, the South African experience. Pages 67-79 in G. I. Cowan, J. Yawitch, and M. Swift, editors. Strategic innovations in biodiversity experience-the South African experience. Department of Environmental Affairs and Tourism, Pretoria, South Africa.

Ramutsindela, M. 2004. Parks and people in postcolonial societies: experiences in Southern Africa. Kluwer, London, UK.

Roe, D., and J. Elliott. 2006. Pro-poor conservation: the elusive win-win for conservation and poverty reduction? Policy Matters 14:53-63

Sanderson, S. E., and K. Redford. 2003. Contested relationships between biodiversity conservation and poverty alleviation. Oryx 37:390.

SANParks. 2007. People and conservation: community-based conservation. [online] URL: htt p://www.sanparks.org/people/community

Sayer, J., and B. Campbell. 2004. The science of sustainable development. Cambridge University Press, Cambridge, UK.
Sayer, J., and M. P. Wells. 2004. The pathology of projects. Pages 35-48 in T. O. McShane and M. P. Wells, editors. Getting biodiversity projects to work: towards better conservation and development. Columbia University Press, New York, New York, USA.

Schmidt-Soltau, K. 2004. The costs of rainforest conservation: local responses towards integrated conservation and development projects in Cameroon. Journal of Contemporary African Studies 22(1):93-117.

Sheridan, M.J. 2008. Introduction: the ecology of fencing. Africa 78(2):153-156.

Springer, J. 2009. Addressing the social impacts of conservation: lessons from experience and future directions. Conservation and Society 7(1):26-29.

Statistics South Africa. 2001. South Africa Census. [online] URL: http://www.statssa.gov.za/p ublications/C2001Stages/C2001Stages.pdf

Sunderland, T. C. H., C. Ehringhaus, and B. M. Campbell. 2008. Conservation and development in tropical forest landscapes: a time to face the tradeoffs? Environmental Conservation 34(4):276-279.

Wells, M. P., T. O. McShane, H. T. Dublin, S. O'Connor, and K. H. Redford. 2004. The future of integrated conservation and development projects: building on what works. Pages 397-422 in T. O. McShane and M. P. Wells, editors. Getting biodiversity projects to work: towards more effective conservation and development. University Press, New York, New York, USA.

Wilshusen, P. R., S. R. Brechin, C. L. Fortwangler, and P. C. West. 2002. Reinventing the square wheel: critique of a resurgent "protectionist paradigm" in international biodiversity conservation. Society and Natural Resources 15:17-40.

Wittemyer, G., P. Elsen, W. T. Bean, A. C. O. Burton, and J. S. Brashares. 2008. Accelerated human population growth at protected area edges. Science 321:123-126. 